\title{
Proteomic analysis of Plasmodium in the mosquito: progress and pitfalls
}

\author{
M. N. WASS ${ }^{1}$, R. STANWAY ${ }^{2,3}$, A. M. BLAGBOROUGH ${ }^{2}$, K. LAL ${ }^{2}$, J. H. PRIETO ${ }^{4}$, \\ D. RAINE ${ }^{2}$, M. J. E. STERNBERG ${ }^{1}$, A. M. TALMAN ${ }^{2,5}$, F. TOMLEY ${ }^{6}$, J. YATES III ${ }^{4}$ \\ and $\mathrm{R}$. E. SINDEN ${ }^{2} *$ \\ ${ }^{1}$ The Centre for Bioinformatics, Department of Life Sciences, Imperial College, London SW7 $2 A Z$ \\ ${ }^{2}$ The Malaria Centre, Department of Life Sciences, Imperial College, London SW7 $2 \mathrm{AZ}$ \\ ${ }^{3}$ University of Bern, Institute of Cell Biology, Baltzerstrasse 4, CH-3012 Bern \\ ${ }^{4}$ The Scripps Research Institute, 10550 North Torrey Pines Rd., Department of Chemical Physiology, SR11, La Folla, CA \\ 92037 \\ ${ }^{5}$ Department of Microbial Pathogenesis, Yale University School of Medicine, 295 Congress Avenue, New Haven, CT 06519 \\ ${ }^{6}$ Pathology $\mathcal{E}^{\circ}$ Infectious Diseases, The Royal Veterinary College, Hawkshead Lane, North Mymms, Hatfield, Hertfordshire \\ AL9 $7 T A$
}

(Received 17 November 2011; revised 10 Ganuary 2012; accepted 11 Fanuary 2012; first published online 16 February 2012)

\section{SUMMARY}

Here we discuss proteomic analyses of whole cell preparations of the mosquito stages of malaria parasite development (i.e. gametocytes, microgamete, ookinete, oocyst and sporozoite) of Plasmodium berghei. We also include critiques of the proteomes of two cell fractions from the purified ookinete, namely the micronemes and cell surface. Whereas we summarise key biological interpretations of the data, we also try to identify key methodological constraints we have met, only some of which we were able to resolve. Recognising the need to translate the potential of current genome sequencing into functional understanding, we report our efforts to develop more powerful combinations of methods for the in silico prediction of protein function and location. We have applied this analysis to the proteome of the male gamete, a cell whose very simple structural organisation facilitated interpretation of data. Some of the in silico predictions made have now been supported by ongoing protein tagging and genetic knockout studies. We hope this discussion may assist future studies.

Key Words: Plasmodium, mosquito, proteome, ookinete, micronemes, surface, microgamete.

\section{INTRODUCTION}

By the mid 1980s dissection of the malaria life cycle by electron microscopy had largely been accomplished. From this morphological analysis it was recognised that the parasite essentially employed just three cell strategies, namely: (1) invasion/dispersal as the parasites move from cell-to-cell and host-to-host; (2) vegetative growth/cell replication in the liver, in the bloodstream of the vertebrate host, and in the haemocoele of the mosquito vector; and (3) sex-which begins in the formation of dimorphic gametocytes in the bloodstream of the vertebrate host and progresses through gamete formation, fertilization and meiosis in the young ookinete-all within the bloodmeal of the mosquito vector (Sinden, 1978). Concurrent studies on the dormant liver stages responsible for relapses in $P$. vivax (hypnozoites) had characterized these elusive parasites at the levels of biology and light microscopy (Krotoski, 1985), however the possible physiological parallels with the arrested gametocyte and sporozoite as they await transmission to and from the mosquito vector, had not yet been recognised.

* Corresponding author: email: r.sinden@imperial.ac.uk.
The sequencing of the genomes of the malarial parasites, their human and rodent laboratory hosts and the mosquito vector has since revolutionised the molecular analysis of the parasite life cycle. The resultant potential of both high throughput transcriptomic- (Kappe et al. 2001; Bozdech et al. 2003; Silvestrini et al. 2005) and proteomic-analysis (Lasonder et al. 2002, 2008; Florens et al. 2002; Hall et al. 2005; Khan et al. 2005; Tarun et al. 2008) to dissect the parasite differentiation through the life cycle has been illuminating.

Recognising the very high throughput possible using microarray technologies why have we chosen the more challenging proteomic approach? For our laboratories two drivers existed: first having described the parasite at the ultrastructural level the inevitable question to arise was 'What are all these exquisite structures actually doing, and what are the molecular complexes/machines by which they achieve these functions?' As an example, as we write this manuscript we read that the sole purpose of one rudimentary, but nonetheless complex organelle-the apicoplast-is apparently 'just' the production of isopentenyl pyrophosphate (Yeh and deRisi, 2011). Second, whilst studying the expression of a major ookinete surface antigen 
Table 1. The composition and quantities of the parasite and cell samples used to generate individual proteomes, and the resultant number of protein 'hits' identified.

\begin{tabular}{lllll}
\hline \hline Stage & Cell fraction & Purity (by microscopy) & Quantity & Hits \\
\hline Liver stages & N.D & NA & NA & NA \\
Asexual blood stages & Whole cell & $100 \%$ & $>2 \times 10 \mathrm{e} 8$ & 1139 \\
Gametocytes & Whole cell & $\sim 80 \%$ & $3 \cdot 5 \times 10 \mathrm{e} 7$ & 733 \\
Male gamete & Whole cell & $\sim 98 \%$ & $1 \cdot 00 \mathrm{E}+08$ & 476 \\
Ookinete & Whole cell & $95-97 \%$ & $3 \cdot 5 \times 10 \mathrm{e} 7$ & 1091 \\
& 'Surface' & $95 \%$ & $\sim 5 \times 10 \mathrm{e} 8$ & 518 \\
Oocyst & 'Microneme' & $97 \%$ & $\sim 2 \cdot 5 \times 10 \mathrm{e} 9$ & 345 \\
Sporozoite & Infected mosquito guts & V. low & 1000 guts & 277 \\
\hline \hline
\end{tabular}

(Pbs21/Pbs28) we had noted that whilst the encoding gene was transcribed in the gametocyte, the protein was only expressed many days later in the macrogamete-ookinete (Paton et al. 1993), thus we were aware that the concept of 'just in time' gene transcription/translation (Bozdech et al. 2003; Olszewski et al. 2010) was by no means universal. In attempting to unravel the architecture of the parasite at the molecular level we remain acutely aware that merely describing the presence of proteins does not imply functional activity. In this context we are reminded of the numerous post-translational modifications that may precede biological activation of any protein complex (Foth et al. 2011; Treeck et al. 2011).

We make no attempt to review the wider literature on malaria proteomics, for this see (Carucci et al. 2002; Kooij et al. 2006), but rather provide a distillation of our personal experiences in generating the 8 separate proteomic studies on the rodent malaria parasite Plasmodium berghei in the mosquito vector (Hall et al. 2005: Stanway, 2007; Lal et al. 2009; Talman, 2010). This focus in no way detracts from the numerous penetrating analyses of the bloodstage parasites and notably of the merozoite (Sam-Yellowe et al. 1998, 2004; Florens et al. 2002; Silvestrini et al. 2005), and the heroic efforts to describe the pre-erythrocytic parasite (Carucci et al. 2002; Doolan et al. 2003; Wang et al. 2004; Blair and Carucci, 2005).

The composition of the life stages, and the cell fractions we have studied are listed in Table 1. The purpose of the studies were: a comparative analysis of the molecular composition of life stages with similar cell strategies, and the appreciation of the scale of translation control in the macrogametocyte (Hall et al. 2005); the identity and molecular capacities of the ookinete secretory organelles (Lal et al. 2009), and ookinete cell surface (Stanway, 2007). The latest study, on the microgamete proteome (Talman, 2010), was motivated by the fact this is the simplest eukaryotic cell known to us, possessing 'just' a repressed/condensed nucleus, an axoneme and a plasma membrane, thus offering an exciting opportunity to attempt an in silico approach to the understanding of its cell structures and functions.
Whilst highlighting some of the successes of these studies we also describe some of the numerous 'confounding factors' that compromised the generation and analysis of the data in the hope that this may help others contemplating similar approaches. In particular we have attempted to refine and strengthen some of the bioinformatic approaches to the analysis of large proteome datasets, the methods for which are outlined here.

\section{MATERIALS AND METHODS}

\section{Parasite preparation}

Parasite. The parasites used for these studies were Plasmodium berghei clone 2.34 (wild-type), and clone 2.33 a line that fails to produce mature gametocytes (used for the preparation of mixed asexual bloodstages). Additionally knockout sub-clones of 2.34 in which either one or both of the genes encoding the dominant surface antigens $\mathrm{Pb} 28$ (clone b28sko), Pb25 (clone b25sko), Pb25\&28 (clone b25/28dko) had been deleted were used to study methods for cell surface biotinylation.

Parasites were either stored over liquid nitrogen or maintained in Tucks Original mice by mechanical passage, and transmitted though mosquitoes every $8^{\text {th }}$ blood transfer. All details of the preparation of the separate life stages, and of microneme fractions are as described previously (Hall et al. 2005; Lal et al. 2009).

\section{Labelling ookinete surface proteins}

Biotinylation. Ookinetes were purified from mature cultures (Lal et al. 2009) by binding to antiP28 monoclonal antibody-coated magnetic beads. Ookinetes were washed in PBS at $\mathrm{pH} 8.0$ and incubated with EZ-Link ${ }^{\circledR}$ Sulfo-NHS-LC-Biotin (Pierce, UK) for 30 minutes. The biotinylation reaction was stopped by incubation with $50 \mathrm{mM}$ $\mathrm{NH}_{4} \mathrm{Cl}$. Ookinetes were washed in $50 \mathrm{mM}$ Tris- $\mathrm{HCl}$, $\mathrm{pH} 7 \cdot 4$ and were then lysed by passing through a 25 gauge needle in buffer containing $7 \mathrm{M}$ Urea, $2 \mathrm{mM}$ DTT, $0 \cdot 1 \%$ SDS and Complete Mini Protease 
Inhibitor Cocktail (Roche Applied Science). The lysate was centrifuged at 15000 r.c.f. for 30 minutes at $4{ }^{\circ} \mathrm{C}$ and the supernatant was diluted 20 -fold with PBS, $\mathrm{pH} 8 \cdot 2$, prior to incubation in binding buffer with streptavidin Sepharose ${ }^{\circledR}$ high performance beads (Amersham Biosciences, UK), prepared according to the manufacturer's instructions. The beads were washed in $0 \cdot 1 \% \mathrm{SDS}, 50 \mathrm{mM}$ Tris, $\mathrm{pH} 8 \cdot 0$, followed by $50 \mathrm{mM}$ Tris, $\mathrm{pH} 8.0$ and incubated for 25 minutes in $8 \mathrm{M}$ urea and $100 \mathrm{mM}$ trisphosphine hydrochloride (TCEP) to denature and reduce proteins, respectively. Beads were incubated in $500 \mathrm{mM}$ iodoacetamide for 25 minutes and then $1 \mu \mathrm{g}$ sequencing grade endoproteinase Lys-C (Roche Applied Science) added for 6 hours at $37^{\circ} \mathrm{C}$, followed by $1 \mu \mathrm{g}$ sequencing grade modified trypsin (Promega) in $50 \mathrm{mM}$ Tris, $\mathrm{pH} 8.0$ overnight. The supernatant was removed, formic acid added to a concentration of $5 \mathrm{mM}$ and the sample lyophilised.

Iodination. Ookinetes purified as above were surface iodinated using IODO-BEADS ${ }^{\circledR}$ Iodination Reagent (Pierce) and Iodine ${ }^{125}$ ( $\mathrm{NaI}$ in $0.01 \mathrm{~N} \mathrm{NaOH}, \mathrm{pH} 8-$ 11, $100 \mathrm{mCi}$, MP Biomedicals). $500 \mu \mathrm{Ci} \mathrm{NaI}{ }^{125}$ were incubated with $20 \mathrm{IODO}-B E A D S^{\circledR}$ and the purified ookinetes for 15 minutes. The beads were removed and the ookinetes washed in RPMI. Total ookinete proteins were subjected to SDS-PAGE and autoradiography to profile the molecular motilities of iodinated proteins. Iodine ${ }^{125}$ labelled samples were analysed by 1-D SDS gel chromatography and selected labelled bands identified by western blotting with available monoclonal antibodies.

CyDye labelling. Affinity-purified ookinetes were incubated in Hank's balanced salt solution (HBSS) containing $1 \mathrm{M}$ urea and either $\mathrm{Cy} 3 \mathrm{CyDye}^{\mathrm{TM}}$ or $\mathrm{Cy} 5$ $\mathrm{CyDye}^{\mathrm{TM}}$ (GE Healthcare) on ice for 20 minutes. The labelling reactions were quenched on ice for 10 minutes with $10 \mathrm{mM}$ lysine. Cells were washed in HBSS and subjected to two-dimensional gel electrophoresis. Isoelectric focussing on Immobiline Dry Strips $^{\mathrm{TM}}$, pH 3-10, $11 \mathrm{~cm}$ (Amersham Biosciences) was followed by SDS-PAGE gel electrophoresis in $4-12 \%$ Criterion $^{\mathrm{TM}}$ XT precast gradient gels (Biorad Laboratories). Gels were stained with $80 \%$ Brilliant blue G-colloidal concentrate (Sigma) and de-stained with $1: 17 \%$ acetic acid: $25 \%$ methanol, followed by $25 \%$ methanol.

\section{Proteomics}

MudPIT analysis of all samples has been described in detail previously (Hall et al. 2005; Lal et al. 2009; Talman, 2010). CyeDye labelled samples of ookinete surface proteins were separated by $2-\mathrm{D}$ gel chromatography and the labelled spots excised and analysed by Q-TOF mass spectrometry by Dr. R. Wait of the Kennedy Institute of Rheumatology, London.

Spectral Analyses. All the data reported here with the exception of the microgamete proteomes were derived from filtered spectra prepared using SEQUEST (version 27) and the $P$. berghei genome annotation then available (Hall et al. 2005) derived from the $3 \mathrm{x}$ coverage sequence of the genome. This primary analysis was complemented by use of the $8 \mathrm{x}$ $P$. yoelii library (Carlton et al. 2002). The NCBI common contaminant, mouse and mosquito databases and a reverse database (Peng et al. 2003) were used to remove contaminating and false spectra. Results were assembled and filtered using DTASelect (version 2). Where possible we made 10 runs on each preparation in an attempt to achieve 95\% coverage of the complex mixtures being studied.

\section{Bioinformatic analysis methods}

All samples, with the exception of the microgamete proteomes, were analysed manually as described previously (Hall et al. 2005; Lal et al. 2009).

Automated prediction of subcellular localisation of microgamete proteins. Recognising the relatively restricted number of cell locations and cell functions of the microgamete we surmised this might permit additional automated and parallel in silico approaches to data analysis. To predict subcellular localisation for the gamete protein, initially tmHMM (Krogh et al. 2001) and SCAMPI (Bernsel et al. 2008) were used to identify transmembrane proteins. Where there was no agreement TOPCONS (Bernsel et al. 2009) was used to provide a consensus transmembrane prediction. SignalP (Emanuelsson et al. 2007) was used to predict signal peptides, and multiple predictors were used for subcellular localisation: WOLF PSORT (Horton et al. 2007), Sherloc2 (Briesemeister et al. 2009), ESLPred2 (Garg and Raghava, 2008), Euk-mPLoc (Chou and Shen, 2007) and Cello (Yu et al. 2006). Their predictions were combined to give consensus analyses. Additionally the keywords identified from Interpro (Hunter et al. 2009) hits for the sequences were used to infer localisation. As examples histone, DNA, HMG (high mobility group) and nucleosome infer nuclear location, and in the case of the microgamete actin, kinesin and tubulin infer axonemal/flagellar location. The locations inferred are based on the knowledge from electron microscopy of the limited subcellular locations present in the gamete and clearly will not necessarily hold true for other complex cell types.

Automated prediction of protein function. Protein function was predicted using multiple prediction 
methods. Interpro (Mulder et al. 2007) domain hits were mapped to Gene Ontology (GO) (Ashburner et al. 2000) functions using the Interpro-to-GO mapping provided by Interpro. Additionally the Pfam domain combinations were used to predict GO functions (Forslund and Sonnhammer, 2008). GO functions were also predicted using ConFunc (Wass and Sternberg, 2008), PFP (Hawkins et al. 2006) and FFPred (Lobley et al. 2008). The fold library of the protein structure prediction server Phyre2 (Kelley and Sternberg, 2009) was searched and the functional annotations of the hits in the Enzyme Classification (Bairoch, 1999) and GO were identified. 3DLigandSite (Wass et al. 2010) was used to predict small molecule ligand binding sites.

Manual prediction of location and protein function.

Final predictions of both subcellular localization and protein function were made manually by analysing the results of the automated methods and by making further reference to the literature and to additional information available e.g. PlasmoDB/EuPath. This included the subcellular locations for proteins that are present in apiloc (http://apiloc.bio21.unimelb. edu.au/apiloc/apiloc), which contains subcellular locations extracted from literature. Our manual predictions of both function and subcellular localization are associated with descriptions of the data used to make the prediction. All results are available at http://www/sbg.bio.ic.ac.uk/ mwass/plasmodium.

\section{RESULTS AND DISCUSSION}

Recognising the specific objectives of this symposium, the results and discussion presented here will focus on the methodological issues specifically relating to Plasmodium. Thus we specifically exclude discussion on the relative merits of the proteomic methods used e.g. MudPIT vs. gel-LC/MS/MS a robust debate presented elsewhere (Lasonder et al. 2002).

\section{Life cycle stages}

Asexual blood stages. In 2005 we published a comparative proteome of the life stages of $P$. berghei in which a 'reference' preparation of asexual blood stages was derived from mice infected with a gametocyte-less clone 2.33 (Hall et al. 2005). We now have reason to doubt the original phenotypic characterization of this clone. Briefly; for some 20 years we had observed clone 2.33 and never found any evidence for the presence of mature gametocytes in the blood of infected mice by light or electron microscopy, nor by molecular analysis of late stage gene products (e.g. mRNA of P28). Whilst recognising the identical morphologies and similar metabolic profiles of the immature gametocytes and the asexual trophozoite, it was not until the publication of Deligianni et al. (2011) that evidence emerged that clone 2.33 may form immature gametocytes (which then fail to develop). Thus the proteome for the asexual blood stages reported by us (Hall et al. 2005), must now carry the caveat 'the asexual, and immature sexual blood stages'! For us this is a lesson well learnt, and in retrospect represents a 'Rumsfeldian' unknownunknown.

The calculated $81 \%$ coverage of the genome achieved in the proteomic analysis of the $P$. berghe $i$ life cycle (Hall et al. 2005), permitted interesting global comparisons to be made between the different life strategies (invasion, replication and sex) and stages (e.g. within the invasion strategy-merozoite; sporozoite; ookinete). Parasite stages within a 'strategy' were found to share a greater proportion of proteins than are committed to the unique activities distinguishing individual stages (see Fig. 1). Lasonder et al. (2008) similarly found stage-specific protein expression to represent just $\sim 12$ to $\sim 28 \%$ of all proteins expressed by that stage. An unexpected finding was that the male gamete, despite being entirely derived from the microgametocyte in a process lasting just 15 minutes, nonetheless $34 \%$ of the proteins found in the gamete have not yet been described in the proteome of the un-activated gametocyte. These proteins are therefore either synthesised de novo during the process of exflagellation, or they represent a group of molecules 'lost' from the gametocyte proteome for technical reasons (low abundance or recovery).

Where significant proteomes exist for any life stage, we have often found the apparent absence/presence of individual proteins to be in error. Conversely, we have found the presence or absence of functionally related groups of proteins in replicate experiments a compelling entrée to understand their biology. Thus, in the case of the ookinete, in which both micronemes and rhoptries had been identified by electron microscopy (Sinden, 1978), the absence of the known rhoptry proteins paralleled by the presence of a large and broadly representative group of known microneme proteins prompted our conclusion that the ookinete lacked rhoptries (Lal et al. 2009). The ability to test this hypothesis using protein tagging studies (Tufet-Bayona et al. 2009) validated this hypothesis. This re-analysis then provided a rational molecular understanding for the contrasting biological observations that midgut epithelial cells invaded by ookinetes are lysed and die, expressing vATPase (Shahabuddin and Pimenta, 1998; Cociancich et al. 1999; Han and Barillas-Mury, 2002) whereas host cell invasion by merozoites and sporozoites (both of which possess rhoptries) permits their respective host cells to survive invasion and support subsequent vegetative growth of the parasite. 

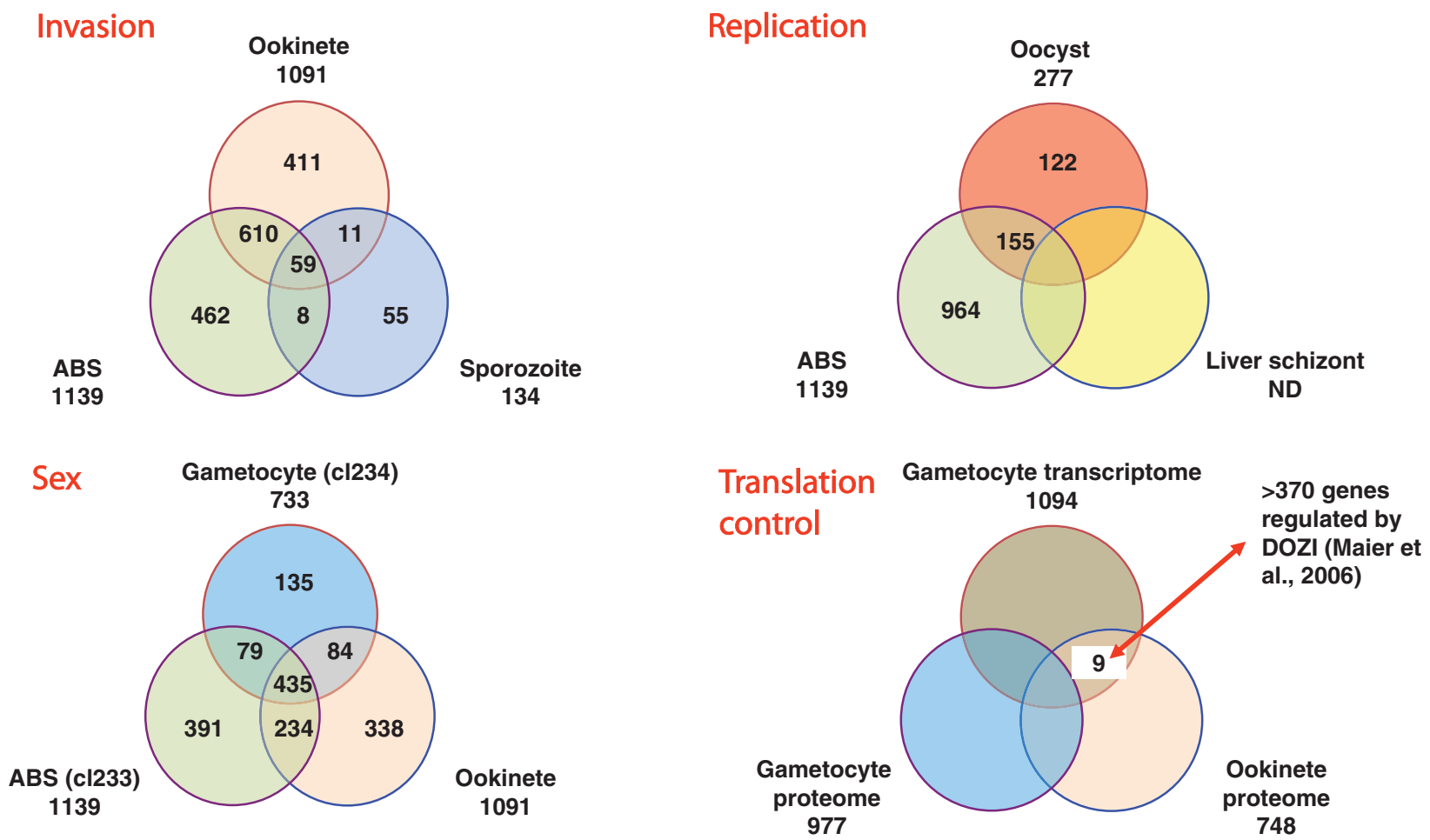

Fig. 1. Venn diagrams to illustrate the distribution of proteins detected in individual life stages that found uniquely in one life stage, or shared between stages within strategy classes (invasion, replication and sex). Proteins subject to translation control were identified as those found uniquely as mRNA in the gametocyte but as protein in the ookinete. (Modified from Hall et al. 2005)

Sporozoites which transit multiple host cells prior to beginning vegetative growth in the liver may therefore be hypothesised to employ phased/regulated secretion of the micronemes (traversal and residency) and rhoptries (residency).

A second example of the utility of observations on molecular groups has been the integration of transcriptomic and proteomic data to understand protein expression in the mature female gametocyte. The identification of 9 proteins in the ookinete that were present as transcripts but not proteins in the mature female gametocyte (Hall et al. 2005), combined with the knowledge that for one of these proteins (P28/ $\mathrm{Pbs} 21)$ convincing data existed for the presence in the macrogametocyte of the message in discrete cytoplasmic structures ('Thompson and Sinden, 1994) provided provocative evidence for the wider use of translational control mechanisms in Plasmodium biology (Fig. 1). Subsequent elegant molecular dissection of this concept followed, leading to the recognition that as many as 370 proteins may be suppressed at the level of translation in the gametocyte (Mair et al. 2006). Noting the similar strategic positions of the gametocyte and the sporozoite in the parasite life cycle - both are terminally differentiated cells that must survive extended periods in one host before having to respond rapidly to the environment of the new host following transmission - it is interesting to note translational control mechanisms are employed by both (Gomes-Santos et al. 2011). It would be fascinating to understand whether similar mechanisms also regulate the remaining 'latent' stage, the hypnozoite.

The microgamete. One of the most recent, and currently unpublished, proteomes we have produced is from the intact microgamete. Our reasons for undertaking the challenge of preparing this very rare and physically small stage of the life cycle are manifold. First, it occupies a critical point in the parasite life cycle and one that has become the focus of much attention since the recognition of the key roles of gametogenesis, fertilisation and ookinete development in the development of new and powerful transmission-blocking intervention strategies (Wells et al. 2009). Second, the preparation of the parasite material required no subcellular fractionation steps that might change the protein composition of the preparation. Third, our previous electron microscopic studies (Sinden et al. 1976; 1978, Sinden, 1983), supported by later genetic analyses (Creasey et al. 1993; Okamoto et al. 2008) suggested the microgamete has essentially just 4 cellular compartments: a nucleus in which lies a condensed genome; an axoneme; cytoplasm and cell membrane. This we anticipated might offer a simplified dataset for the development of improved methods for the bioinformatic analysis of data (and its validation by genetic manipulation techniques) as described below. The publication of these data has 


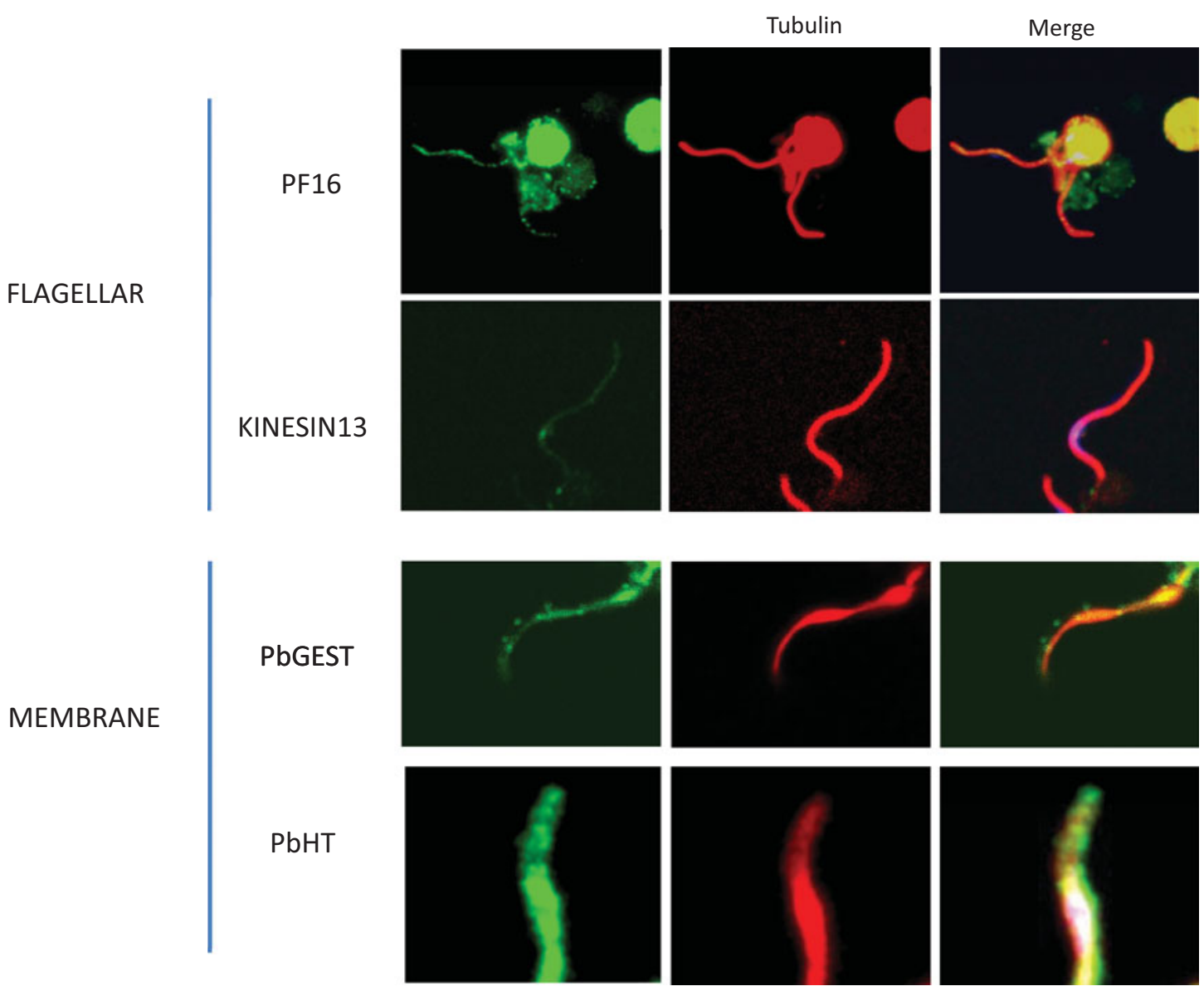

Fig. 2. All proteome-predicted male gamete proteins we have attempted to localize thus far have been found in situ in the male gamete: PF16 (Straschil et al. 2010), Kinesin13 (Marques, unpublished), PbGEST (Talman et al. 2011) and PbHT (Slavic et al. 2011).

been delayed by the 'inconvenient' publication of a revised $P$. berghei genome, which required a complete re-analysis of all the spectra against the new gene models, a substantial exercise that changed 152 of 624 protein identifications!

Recognising prior conclusive evidence that the microgamete lacked a mitochondrion, it was surprising that despite strong evidence that the microgamete preparations lacked significant cellular contamination, the proteome contained a few mitochondrial proteins (see below). Whilst it has been long established that microgamete motility is dependent upon extracellular glucose (Nijout and Carter, 1978), nonetheless the abundance of all 11 enzymes of the glycolytic pathway, and the hexose transporter $(\mathrm{PbHT})$ in the proteome was surprising, as was our corresponding failure to detect a putative lactate transporter (Martin et al. 2009). The presence/ activity of a lactate transporter may be a key regulator of both the fast/slow flagellar activity and the brief ( $\sim 40 \mathrm{~min}$.) life of the gamete. Validation of the importance of glycolysis was achieved in two ways first by location of a C-terminus myc-tagged $\mathrm{PbHT}$ to the gamete surface (see Fig. 2), and second by demonstrating the impact of inhibitors of glycolysis upon motility. The outstanding question still to be resolved is to ask whether/how lactate is removed from the cell?

Whilst the axoneme is the most prominent structure in the microgamete, cytoskeletal (axoneme-related) proteins represented just $6 \%$ of all proteins identified by our techniques. Downstream analysis of location and 'functions' of those identified has nonetheless proved a fertile area of study (see Fig. 2) that will have an important role to play in unravelling the molecular organisation of the spectacularly rapid process of exflagellation, notably in the spatial organisation of the nucleating centromeres/ basal bodies (Straschil et al. 2010; Marques, unpublished data) and the intracellular assembly of the 8 axonemes (Sinden et al. 2010).

Perhaps the most important contribution of the microgamete proteome in the longer term may be the identification of 23 putative surface molecules, each of which must now be pursued to question their roles in fertilization and their potential for development as targets for transmission-blocking antibodies. Amongst these proteins were some that prior evidence has suggested very strongly to be synthesised exclusively in the female gamete cell lineage e.g. the LAP/CCCP proteins and p47 (Khan et al. 2005; van Schaijk et al. 2006; Scholz et al. 2007). 
Recognising that we were unable to detect any female gametes in the originating cell preparation we are led to question the mechanism explaining their presence in the proteome. Amongst many others, one interesting possibility we are pursuing, surmises that these female proteins may specifically bind to the male extracellular surface (should they be released into the medium). Thus these female 'contaminants' have become priority candidates in our search for additional fertilisation ligands.

\section{Analysis of cell fractions}

When embarking on the proteomic dissection of cell fractions we had hoped that the anticipated enrichment of proteins would unambiguously identify molecules with key roles in the activity of that sample. It is perhaps this hope that has been most profoundly dented. Whereas the cellular composition of whole cell preparations of life cycle stages may be considered relatively undemanding (but certainly not infallible), the composition and origins of components in cell fractions has posed insurmountable hurdles for these applications.

The ookinete surface. Three broad methodologies exist for the generation of surface proteomes. One of the most commonly used techniques has been the combination of cell lysis and differential centrifugation and/or sucrose gradient flotation to purify the plasma membrane. Whilst fractionation has proved successful for proteomic analysis of Plasmodium rhoptries and of the micronemes of $P$. berghei ookinetes (see below), we anticipated that the close association of the plasma membrane and underlying inner membrane complex would be likely to lead to co-purification of this entire alveolar structure, the subsequent rigorous detergent lysis required to disrupt this complex could dissociate some surface-exposed proteins. Trypsin 'shaving', a method successfully employed to analyse the merozoite/RBC interactions (Hadley and Miller, 1988), was discounted because the ookinete naturally lives in an environment rich in this enzyme (Gass, 1977; Gass and Yeates, 1979; Muller et al. 1993). We therefore chose to label and then affinity-purify surfaceexposed proteins from cultured, purified, intact ookinetes. Preliminary comparative analysis of W'T, P28ko, P25ko and P25/P28 double ko ookinetes showed these key ookinete surface proteins could be labelled readily with sulfo-NHS-LC-biotin. Biotinylation identified 518 proteins, of which 67 were predicted to harbour a signal peptide and/or transmembrane domain. Of the 16 known ookinete surface proteins, 15 were identified in the dataset. To compare the data with the whole ookinete proteome (Hall et al. 2005), the Relative Spectral Abundance (RSA) was calculated for each of the 320 proteins detected in both the surface and whole ookinete proteomes. The proportion represented by each protein of all spectra in either dataset was calculated, giving two spectral proportion values $\mathrm{SP}_{\text {surface }}$ and $\mathrm{SP}_{\text {whole }}$. When $\left(\mathrm{SP}_{\text {surface }}-\mathrm{SP}_{\text {whole }}\right)>1$ proteins were considered to be enriched in the surface proteome. Of the 50 proteins most enriched in the surface proteome (Table 2), six are known to be surface associated or secreted (P28, P25, CTRP, LAP1, LAP2 and chitinase). Whilst the ookinete surface may still hold some surprises, as recently suggested by the descriptions of enolase and actin on the ookinete plasma membrane (Hernandez-Romano et al. 2011), many of these 'enriched proteins' are highly unlikely to be found naturally on the ookinete surface e.g. histones $\mathrm{H} 2 \mathrm{~A}$ and $\mathrm{H} 2 \mathrm{~B}$ (previously surface located (Watson et al. 1995)), dynein and ATPdependent RNA helicase. Amongst those proteins with an $\mathrm{RSA}<1$, i.e. depleted, were some such as von Willibrand factor A domain Related Protein (WARP), previously found on the ookinete surface. In trying to understand this 'depletion', we are reminded that the methodology does not report the final /functional location of a protein, but rather reports the fraction of that protein that is resident in a sample at the time of labelling, thus proteins whose trafficking to the surface is highly regulated (i.e. a high proportion of the total is in cytoplasmic vesicles) might appear to be surface depleted by this analysis.

We were challenged by the presence of so many intracellular proteins in these 'surface' fractions. We noted many of the proteins belonged to the actinmyosin motor complex, which is known to be located immediately beneath the plasma membrane and associated with the inner membrane complex (see Fig. 3). In retrospect we then examined, during the surface biotinylation procedure, the permeability of ookinetes by exposing them to propidium iodidewhich reportedly only enters cells whose plasma membrane is compromised. Following affinity purification; washing in $\mathrm{PBS} \mathrm{pH} 8.0$; and biotinylation, we saw $6 \% ; 21 \%$; and $75 \%$ respectively of the ookinetes were permeant to the dye. It was then unsurprising that we had biotinylated intracellular proteins. We nonetheless recognise other factors may also contribute to cytoplasmic contamination of these proteomes e.g. failure to quench the biotinylation reagent following labelling, and non-specific binding of proteins to streptavidin.

We attempted to validate the biotinylated surface proteome by both surface iodination and CyDye technologies. Surface iodination, followed by SDSPAGE and autoradiography suggested the ookinete surface is dominated by two proteins, identified as P25 and P28 in Western blots. CyDye methods similarly identified both P25 and P28, but additionally labelled actin and protein disulphide isomerase (PDI). PDI has been described on the surface of 
Table 2. The 50 proteins detected with the most spectra in the ookinete surface proteome. Proteins shown in Bold are those known to be on the ookinete surface and those in italics have a predicted surface localisation.

\begin{tabular}{|c|c|c|c|c|c|}
\hline \multirow{4}{*}{\multicolumn{3}{|c|}{$\begin{array}{l}\text { spectra in the ookinete surface proteome. Proteins } \\
\text { shown in Bold are those known to be on the } \\
\text { ookinete surface and those in italics have a predicted } \\
\text { surface localisation. }\end{array}$}} & \\
\hline & & & Gene ID & Name & Spectra \\
\hline & & & PB000879.01.0 & Hsp60, putative & 42 \\
\hline & & & PB301219.00.0 & Hypothetical protein & 41 \\
\hline Gene ID & Name & Spectra & PB001125.00.0 & Conserved hypothetical & 41 \\
\hline PB000233.00.0 & $\begin{array}{l}\text { CSP- and TRAP-related } \\
\text { protein (CTRP) }\end{array}$ & 274 & PB000198.00.0 & $\begin{array}{l}\text { protein } \\
\text { Conserved hypothetical } \\
\text { protein }\end{array}$ & 41 \\
\hline PB000609.00.0 & Hypothetical protein & 271 & PB000990.01.0 & Mitochondrial processing & 40 \\
\hline PB000857.00.0 & Tubulin alpha chain, putative & 264 & & peptidase alpha subunit, & \\
\hline PB001069.00.0 & Myosin a (MyoA), putative & 262 & & putative & \\
\hline PB001298.00.0 & Disulfide isomerase precursor, & 258 & PB000126.03.0 & RNA helicase-1, putative & 40 \\
\hline PB000865.00.0 & $\begin{array}{l}\text { putative } \\
28 \mathrm{kDa} \text { ookinete surface }\end{array}$ & 248 & PB001334.02.0 & $\begin{array}{l}\text { Secreted ookinete adhesive } \\
\text { protein }(S O A P)\end{array}$ & 38 \\
\hline & & & PB000523.01.0 & $60 \mathrm{~S}$ Acidic ribosomal protein & 35 \\
\hline PB300144.00.0 & Histone h2a, putative & 177 & & P2, putative & \\
\hline PB000164.02.0 & Tubulin beta chain, putative & 149 & PB000298.03.0 & Plasmepsin IV, putative & 35 \\
\hline PB000603.01.0 & $\begin{array}{l}\text { ATP-dependent RNA } \\
\text { helicase, putative }\end{array}$ & 143 & PB000824.03.0 & $\begin{array}{l}\text { Conserved hypothetical } \\
\text { protein }\end{array}$ & 35 \\
\hline PB300720.00.0 & Hypothetical protein & 142 & PB000600.00.0 & Calmodulin-domain protein & 34 \\
\hline PB001177.00.0 & Heat shock protein, putative & 138 & & kinase 4 (CDPK4) & \\
\hline PB000053.00.0 & Endoplasmin homologue & 132 & & & \\
\hline
\end{tabular}

PB000323.01.0 Actin precursor, putative

PB001519.02.0 Hypothetical protein

PB000423.03.0 Elongation factor 1 alpha, putative

PB001022.02.0 FAD-dependent glycerol-3phosphate dehydrogenase, putative

PB000266.01.0 $25 \mathrm{kDa}$ ookinete surface antigen, P25

PB000652.01.0 LCCL/Lectin Adhesive-like Protein 2, PbLAP2

PB000456.03.0 Enolase, putative

PB300531.00.0 Hypothetical protein

PB001096.02.0 Histone H2A variant, putative

PB000131.02.0 Small heat shock protein

PB001040.00.0 Conserved hypothetical protein

PB000418.03.0 PDI-like protein, putative

PB001032.02.0 Chitinase (CHT1)

PB000484.02.0 Hypothetical protein

PB000180.03.0 40S ribosomal protein S7 homologue, putative

PB000817.02.0 Heat shock 70 kDa protein, putative

PB001286.00.0 Polyadenylate-binding protein, putative

PB000860.02.0 Dihydrolipoamide succinyltransferase, putative

PB000977.02.0 LCCL/Lectin Adhesive-like Protein 1, PbLAP1 (PbSR, PbSLAP)

PB000768.03.0 Conserved hypothetical protein

PB300665.00.0 Acid phosphatase, putative (GAP50)

PB000330.03.0 Protein disulfide isomerase related protein, putative

PB001526.02.0 Transmission blocking target antigen precursor, Pbs47

PB301381.00.0 Hypothetical protein

PB000120.01.0 Conserved hypothetical protein

PB001664.02.0 Organelle processing peptidase, putative
Table 2. (Cont.)

Toxoplasma gondii tachyzoites (Meek et al. 2002) and in Neospora caninum has been shown to localise to the micronemes and to be involved in interaction with the host cell (Naguleswaran et al. 2005).

A microneme proteome. Micronemes, together with rhoptries and mononemes, are regulated secretory vesicles that may be found at the anterior of the invasive stages of apicomplexan parasites (Singh et al. 2007). Proteins secreted from these organelles have roles in motility and host cell invasion. The physical composition of our microneme preparations from the ookinete was compelling; the initial ookinete preparation was $97 \%$ pure, analysis of the density gradients by Western blotting revealed significant enrichment of known micronemal proteins in fractions of the anticipated density $(1 \cdot 1 \mathrm{~g} / \mathrm{ml})$. EM observations confirmed the abundance of micronemes but clearly identified other unspecified cell debris (Lal et al. 2009). This enrichment was paralleled by the simultaneous depletion of known surface proteins and proteins predicted to locate at the ER, mitochondria, apicoplast and nucleus. We had anticipated that by determining the RSA, we would uniquely identify micronemal proteins. Micronemal proteins were amongst the most abundant in these fractions and the most enriched $(1.6 \%$ of whole ookinete vs. $18 \cdot 3 \%$ of fraction spectra), but other protein classes were also enriched e.g. ribosomal proteins $(8.4 \%$ of whole ookinete vs. $9 \cdot 7 \%$ of fraction spectra), suggesting in this instance RSA may be less informative. The abundance of micronemal proteins ranged from 1094 spectra (SOAP) to 4 (PPLP4), but some proteins previously reported in this organelle were not found (e.g. Sub-2, PPLP3) ('Table 3). 


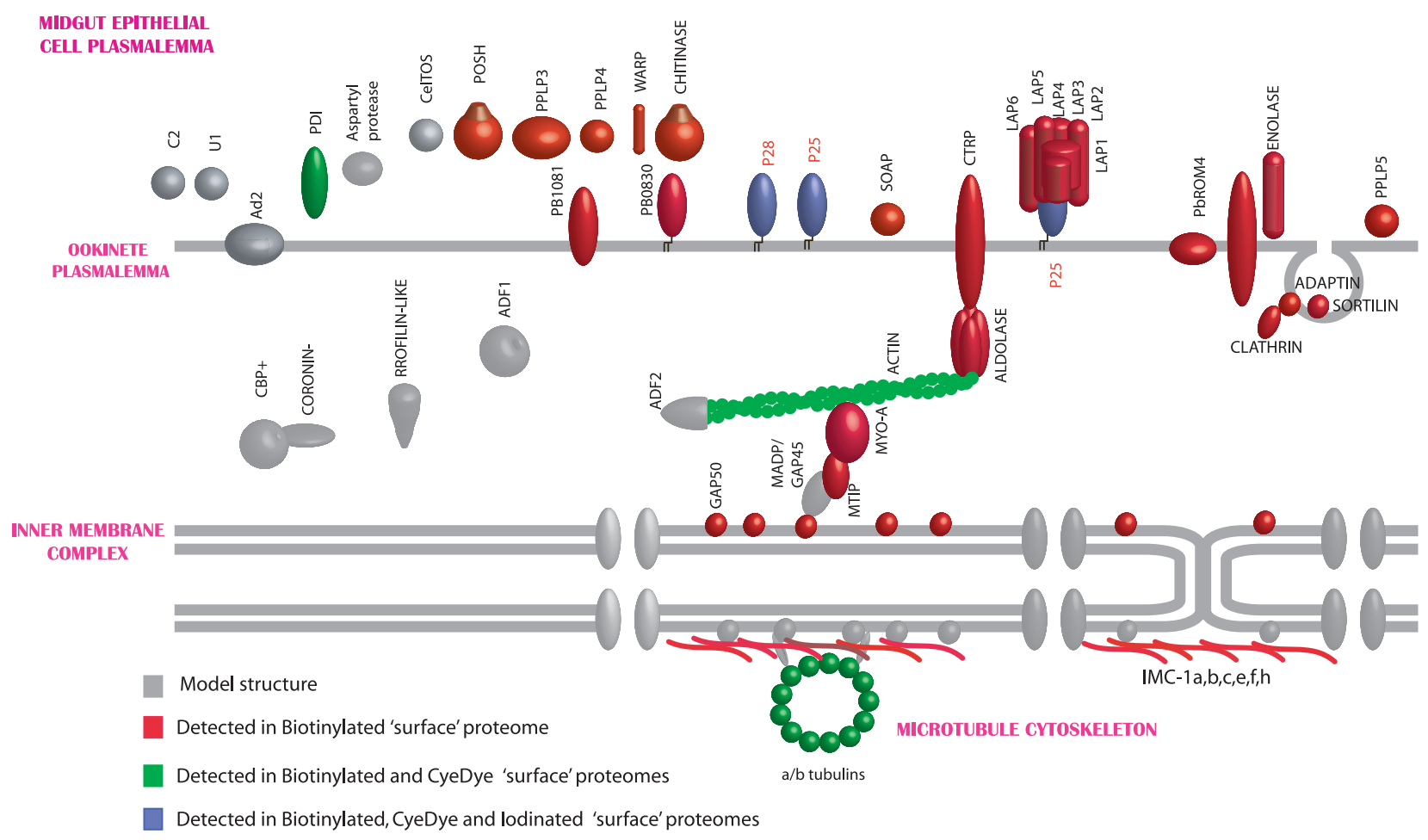

Fig. 3. Diagrammatic representation of molecules detected in the putative surface proteomes of the ookinete, noting how different labelling methods identified proteins from different reported locations. (R.Stanway, 2009)

Quantitative proteomic methods have been examined in detail by others (Nirmalan et al. 2004; Sims and Hyde, 2006; Foth et al. 2011; Southworth et al. 2011). It has been argued that spectral count correlates with protein abundance, but without knowing the individual behaviours of proteins during the preparative steps, we must be cautious in extrapolating these values to the originating cell. Nonetheless, for our purposes the most highly abundant proteins are certainly worthy of attention, thus the high position of PDI in the microneme proteome suggests this chaperone is carried through into the mature secretory vesicle from its presumed initial interaction with cargo proteins in the lumen of the endoplasmic reticulum. Recalling that PDI was also present in the surface proteome we suggest it may be carried from the ER through the micronemes to the parasite surface. Others have suggested extracellular roles for PDI e.g. manipulating glycoprotein interactions ( $\mathrm{Bi}$ et al. 2011) and Chlamydia cell invasion (Abromatis and Stephens, 2009). Whilst the greatest attention has been placed on the identification of protein cargo of the micronemes, it was not unexpected that this enriched vesicle preparation contained many cytoplasmic proteins known to mediate the trafficking of secretory vesicles between the Golgi apparatus and the cell surface. Amongst these, the relative abundance of actin (39 spectra) is entirely consistent with the interesting observation of high concentrations of GFP-tagged actin at the anterior pole of the ookinete where the micronemes ducts fuse with the plasma membrane (Vontas et al. 2005).

\section{Extended bioinformatics analysis}

As stated in the introduction, the prime reason for undertaking proteomic analyses of Plasmodium has been to extend our understanding of parasite biology from the level of the organelle to that of their component molecular machines. The high fraction of hypothetical proteins even in the latest annotations of the malarial genomes constantly frustrates this ambition. Recognising the small size of the parasite genome and potential for 'hybrid' protein functions we have attempted to bring the power of combined bioinformatic approaches to generate possible functions for these 'hypothetical' proteins that can be tested in the laboratory. We have tested this approach using the microgamete proteome for the reasons stated above.

While standard bioinformatics techniques, such as BLAST (Altschul et al. 1990), were able to identify some of the main features of the microgamete, there remained many sequences (182 of 624) with hypothetical or unknown function in PlasmoDB as of December 2010. Additionally many proteins have names but little is known of their function (e.g. early transcribed membrane proteins and BIR proteins) or they have putative functional annotations. The primary aim of our analysis was to identify essential and testable 
Table 3. Proteins with known or putative functions detected in the microneme proteome are shown with the associated number of spectra. Cargo proteins are released from micronemes into the extracellular space with a potential role in invasion. Microneme proteins not detected in this proteome are shown in italics. Vesicle trafficking proteins that may be important to microneme biogenesis, trafficking and secretion are shown. Proteins possibly linked with microneme delivery are termed 'motility' proteins.

\begin{tabular}{|c|c|c|c|c|c|}
\hline \multicolumn{2}{|l|}{ Cargo proteins } & \multicolumn{2}{|c|}{ Vesicle trafficking proteins } & \multicolumn{2}{|c|}{ Motility proteins } \\
\hline Name & Spectra & Name & Spectra & Name & Spectra \\
\hline SOAP & 1094 & Rab11a & 7 & Actin & 39 \\
\hline PDI & 438 & VAMP & 7 & Aldolase & 24 \\
\hline PSOP2 & 434 & Dynamin & 6 & Myosin A & 20 \\
\hline Chitinase & 196 & Clathrin & 5 & MTIP & 7 \\
\hline CTRP & 168 & Sortilin & 4 & $\mathrm{ADF}$ & 5 \\
\hline POSH & 99 & Syn13 & 2 & & \\
\hline WARP & 43 & NSF & 2 & & \\
\hline CelTOS & 29 & & & & \\
\hline AM-1 & 29 & & & & \\
\hline PPLP4 & 4 & & & & \\
\hline$S u b-2$ & 0 & & & & \\
\hline PPLP3/MAOP & 0 & & & & \\
\hline
\end{tabular}

Table 4. Predicted subcellular localisation of Plasmodium berghei microgamete proteome. The number of proteins predicted to be present in each category is shown for whole proteome and also for those proteins that are unannotated.

\begin{tabular}{lrc}
\hline \hline Location & & $\begin{array}{c}\text { Unannotated } \\
\text { proteins }\end{array}$ \\
\hline Cytoplasmic & Gamete & 8 \\
Nuclear & 189 & 27 \\
Plasma Membrane (PM) & 55 & 25 \\
$\quad$ Nuclear membrane & & \\
Cytoplasmic/Nuclear & 64 & 15 \\
PM/Extracellular & 41 & 21 \\
Extracellular & 37 & 19 \\
Flagellar & 36 & 18 \\
PM & 32 & 9 \\
No prediction & 31 & 20 \\
Mitochondrial & 29 & 5 \\
Membrane associated & 15 & 3 \\
Only low confidence & 12 & 10 \\
$\quad$ prediction & & \\
Cytoplasmic/Nuclear/ & 3 & 0 \\
$\quad$ Extracellular & & \\
Cytoplasmic/Flagellar & 3 & 1 \\
Cytopasmic/Mitochondria & 2 & 0 \\
Cytoplasmic/Extracellular & 1 & 1 \\
Cytoplasmic/Flagellar/ & 1 & 0 \\
$\quad$ Nuclear & & \\
Cytoplasmic/Membrane & 1 & 0 \\
Cytoplasmic/Nuclear/ & 1 & 0 \\
$\quad$ Mitochondrial & & \\
Cytoplasmic/PM & 1 & 0 \\
Cytoplasmic/PM/ & 1 & 0 \\
Extracellular & & \\
\hline \hline
\end{tabular}

functions or locations for these hypotheticals. Predictions of location can be particularly useful when a function cannot be predicted e.g. a protein located on the microgamete surface may imply a role in fertilization.
We combined multiple state-of-the-art function prediction and subcellular localisation prediction methods to generate consensus predictions (See Materials and Methods). These consensus predictions were finally analysed manually. It is important to emphasise that this analysis was highly predictive and that while we were able to assign potential functions and/or localisation to a majority (607 of 624), 506 now have predictions for both function and localisation in the microgamete, we nonetheless recognise these predictions require experimental verification.

Location. Table 4 shows the overall results for subcellular localization prediction. The largest fraction of proteins was predicted to be cytoplasmic (189) or nuclear (69). We were able to assign locations to all but 43 of the microgamete proteins, for 12 of these weak predictions could be made but with unacceptably low confidence, for others multiple locations were predicted. Twenty nine of the microgamete proteins in this extended analysis appear to be mitochondrial, which suggested cellular contamination in the sample (see above).

Using 3 different location criteria (intracellular, transmembrane or extracellular/membrane associated/nuclear envelope) the majority (393) of the proteins are intracellular, 103 are transmembrane and 129 extracellular or membrane associated.

We have predicted subcellular localizations for all but 30 of the currently unannotated proteins. The locations predicted are spread throughout the different regions of the gamete (Table 4). The largest fraction of the proteins is predicted to be transmembrane (34 either in the plasma or nuclear membranes). Of the non-transmembrane proteins 27 are predicted to be localized to the nucleus, which is 
Table 5. Predicted functions of the Plasmodium berghei microgamete proteome. The predicted functions generated by the bioinformatics analysis of the proteome are displayed. Numbers are shown for the complete proteome and also for currently uncharacterized proteins in the proteome. The Enzyme* category includes general enzyme functions which not considered highly informative. The Other $\uparrow$ category includes functions that are only predicted for a single protein and are not present in the unannotated set of proteins

\begin{tabular}{|c|c|c|c|c|c|}
\hline Function & Gamete & $\begin{array}{l}\text { Unannotated } \\
\text { proteins }\end{array}$ & Function & Gamete & $\begin{array}{l}\text { Unannotated } \\
\text { proteins }\end{array}$ \\
\hline Metabolism & 93 & 4 & Transcription & 4 & 2 \\
\hline Translation & 65 & 1 & HAD hydrolase & 3 & 2 \\
\hline No prediction & 55 & 53 & Merozoite surface protein & 3 & \\
\hline Transport & 51 & 12 & Post translational modification & 3 & \\
\hline Chaperone & 40 & 1 & Replication & 3 & \\
\hline Flagellar & 39 & 18 & RNA processes & 3 & \\
\hline $\begin{array}{l}\text { Low confidence } \\
\text { prediction }\end{array}$ & 40 & 32 & Splicing & 3 & 1 \\
\hline Signalling & 31 & 11 & CLAG & 2 & \\
\hline Protein trafficking & 18 & 2 & Exported protein & 2 & 2 \\
\hline tRNA synthetase & 15 & & Ookinete surface protein & 2 & \\
\hline Enzyme* & 14 & 4 & Plasmepsin & 2 & \\
\hline Protease & 13 & 5 & Plasmodium antigen & 1 & 1 \\
\hline Chromatin & 11 & 1 & Armadillo-like domain & 1 & 1 \\
\hline Degradation & 10 & & Cell adhesion /Flagellar & 1 & 1 \\
\hline DNA binding & 9 & 7 & Cleft lip palate related & 1 & 1 \\
\hline DNA/RNA binding & 8 & 3 & DNA binding /Flagellar & 1 & 1 \\
\hline $\begin{array}{l}\text { Calcium storage/ } \\
\text { signalling }\end{array}$ & 6 & 4 & $\begin{array}{l}\text { domain: } P . \text { yoelii subtelomeric } \\
\text { PYST-B }\end{array}$ & 1 & 1 \\
\hline RNA binding & 6 & 1 & Dynamin like protein & 1 & 1 \\
\hline DNA processes & 5 & & FAD/NAD binding & 1 & 1 \\
\hline ETRAMP & 5 & & Flagellar/signalling?? & 1 & 1 \\
\hline Phosphatase & 5 & 1 & Lipid binding. & 1 & 1 \\
\hline Rhoptry associated & 5 & & $\begin{array}{l}\text { Oxidative phosphorylation /RNA } \\
\text { editing }\end{array}$ & 1 & 1 \\
\hline Sexual stage antigen & 5 & & Phage fibre protein & 1 & 1 \\
\hline Ubiquitin related & 5 & 1 & Phospholipid rearrangement & 1 & 1 \\
\hline BIR & 4 & & Other† & 19 & 0 \\
\hline Cell division & 4 & 1 & & & \\
\hline
\end{tabular}

nearly $40 \%$ of all the proteins predicted to be present in the nucleus. Many of the uncharacterized proteins are predicted to be either extracellular or associated with the plasma-membrane. Due to their location it is possible that some of the proteins have roles in fertilisation, potentially including recognition of the female gamete.

Function. A summary of the function predictions for the microgamete proteins is shown in Table 5. In this summary the proteins have been assigned to one of three different functional types. Those for which we have made the most informative predictions have been assigned to a process (e.g. translation). Where it has not been possible to predict the biological process, it has often been possible to predict a function (e.g. protease or DNA binding). For some proteins just a domain has been identified (e.g. armadillo-like domain), but in these 'extreme' cases we appreciate this may have little relevance to the true protein function.

Function predictions for the unannotated proteins is more challenging than predicting their subcellular localizations and we have predicted functions for 98 of the 182 proteins. The predicted functions are spread throughout many different areas from transport (including transporters), and signalling to processes regulating DNA and RNA. These predictions in combination with the subcellular localization predictions have been used to identify targets for experimental characterization.

Functions for flagellar proteins. Here we use the proteins predicted to be part of the flagellum to provide an example of how the predictions were made. Eighteen uncharacterized proteins were predicted to be potential components (see Table 6). Recognising the axoneme is the sole and dominant cytoskeletal structure in the microgamete most proteins predicted to have cytoskeletal roles (e.g. actin binding) are likely to be associated with this structure (especially if they are not expressed in the proteome of other life cycle stages). Predictions were often based on the combination of individually weak results from different methods. The main features used were the presence of domains that are widely present in, though not exclusive to, flagellar proteins (e.g. WD40 and coiled coils). This 
Table 6. Unannotated Plasmodium berghei proteins predicted to form part of the microgamete flagellum. The features used to make the predictions are displayed. Structural library hits - are structures in the Phyre2 structural library to which microgamete proteins show homology. Coil and $\mathbf{L C}$ indicate if the protein is predicted to have coils and low complexity regions respectively. Predicted GO functions are those predicted by PFP, ConFunc, FFPRED and the mapping of Interpro hits to GO. In this table the main relevant functions predicted from combining the results are displayed. LRR - Leucine rich region

\begin{tabular}{|c|c|c|c|c|c|}
\hline Gene Id & Interpro Domain hits & Structural library hits & Coil & $\mathrm{LC}$ & Predicted GO functions \\
\hline PBANKA_041580 & WD40 - multiple & actin interacting protein & - & yes & no consensus \\
\hline PBANKA_103570 & WD40 - multiple & actin interacting protein & - & - & $\begin{array}{l}\text { Actin/cytoskeleton } \\
\text { binding }\end{array}$ \\
\hline PBANKA_122900 & - & actin regulatory protein & yes & yes & $\begin{array}{l}\text { Actin/cytoskeleton } \\
\text { binding }\end{array}$ \\
\hline PBANKA_112530 & - & - & yes & yes & $\begin{array}{l}\text { Actin/cytoskeleton/actin } \\
\text { filament binding, }\end{array}$ \\
\hline \multirow[t]{2}{*}{ PBANKA_094240 } & WD40 - multiple. & $\begin{array}{l}\text { actin interacting protein } \& \\
\text { Apoptotic protease- } \\
\text { activating factor } 1\end{array}$ & - & yes & Tubulin binding \\
\hline & $\begin{array}{l}\text { PTHR } 22850 \text { - described as } \\
\text { having receptor activity } \\
\text { (weak) }\end{array}$ & & & & \\
\hline PBANKA_145250 & $\begin{array}{l}\text { PTHR23214-structural } \\
\text { molecule activity. }\end{array}$ & - & yes & yes & no consensus \\
\hline PBANKA_111680 & - & $\begin{array}{l}\text { actin interacting protein } \\
\text { (tropomyosin). } \\
\text { short hit to bacterial FadA } \\
\text { adhesin. }\end{array}$ & yes & yes & $\begin{array}{l}\text { motor activity and actin } \\
\text { binding }\end{array}$ \\
\hline PBANKA_103860 & - & 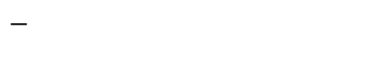 & yes & yes & $\begin{array}{l}\text { motor activity, actin } \\
\text { binding }\end{array}$ \\
\hline PBANKA_145580 & - & $\begin{array}{l}\text { LRR and Coiled coil } \\
\text { proteins }\end{array}$ & yes & yes & actin binding (weak) \\
\hline PBANKA_091450 & $\begin{array}{l}\text { PANTHER - Hydrophilic } \\
\text { surface protein. }\end{array}$ & short hit to fibrinogen & yes & yes & $\begin{array}{l}\text { cytoskeleton binding and } \\
\text { actin binding. Motor } \\
\text { activity }\end{array}$ \\
\hline PBANKA_050970 & - & $\begin{array}{l}\text { microtubule binding } \\
\text { domain \& ATPase } \\
\text { domain. Also hit to ClpA } \\
\text { Chaperone. }\end{array}$ & - & yes & $\begin{array}{l}\text { microtubule motor } \\
\text { activity }\end{array}$ \\
\hline PBANKA_093930 & - & - & yes & yes & $\begin{array}{l}\text { cytoskeleton and actin } \\
\text { binding }\end{array}$ \\
\hline PBANKA_132600 & $\begin{array}{l}\text { PANTHER - structural } \\
\text { constituent of cytoskeleton } \\
\text { and actin binding. } \\
\text { PFAM-guanylate binding } \\
\text { protein }\end{array}$ & $\begin{array}{l}\text { guanylate binding protein } \\
\text { and dynamin }\end{array}$ & yes & yes & no consensus \\
\hline PBANKA_135880 & $\begin{array}{l}\text { PFAM hit to kinetochore } \\
\text { complex - approx } 70 \text { residues }\end{array}$ & $\begin{array}{l}\mathrm{N} \text { terminal - to coiled } \\
\text { proteins (alpha- } \\
\text { tropomyosin, fibrinogen. } \\
\text { C-terminal - kinetochore } \\
\text { protein protein }\end{array}$ & yes & yes & no consensus \\
\hline PBANKA_083090 & $\begin{array}{l}\text { PANTHER - structural } \\
\text { cytoskeleton domain. LRR } \\
\text { (same region) }\end{array}$ & LRR domains & yes & yes & no consensus \\
\hline \multirow[t]{2}{*}{ PBANKA_082290 } & WD40 - multiple & $\begin{array}{l}\text { multiple different } \\
\text { structures with WD40 } \\
\text { domains }\end{array}$ & - & - & $\begin{array}{l}\text { microtubule, dynein, } \\
\text { actin binding. Also } \\
\text { kinase }\end{array}$ \\
\hline & $\begin{array}{l}\text { PANTHER - structural } \\
\text { constituent of cytoskeleton. }\end{array}$ & & & & \\
\hline PBANKA_083300 & Profilin-actin binding & Profilin & - & - & $\begin{array}{l}\text { cytoskeletal protein and } \\
\text { actin binding }\end{array}$ \\
\hline PBANKA_094230 & Radial spokehead-like protein & - & - & - & no consensus \\
\hline
\end{tabular}

was often supported by homologies to actin interacting proteins identified by searches of the Phyre 2 protein structure library. A further source of evidence was the GO predictions made by both
ConFunc and PFP, many examples predicted functions such as cytoskeleton-binding, actin (or actinfilament) binding, motor activity, microtubule motor activity. 
Overall the predictions of flagellar proteins rely heavily on the prediction of a role in the cytoskeleton. While this may be an effective way to predict proteins that may be part of the flagellum, it is also possible that some of these proteins do in fact have functions within the cytoskeleton. This may be more likely for proteins that have predictions that suggest other functions, such as PBANKA_132600 which also has Interpro domain and structural hits to a guanylate binding protein and PBANKA_135880 which also has predictions for a kinetochore function (Table 6).

\section{ACKNOWLEDGEMENTS}

The authors acknowledge the financial support of the BBSRC Grant No. BBS/B/03858 (MNW, MJES, KL, FT), Malpartraining programme (AT) ; EUFP7 Biomalpar, Evimalar and Transmalbloc programmes (RES, SM); The MRC (RS), The Wellcome Trust (DR, AE, KL), Fraunhofer CLB, Delaware (AB); NIH P41RR011823 (JY), NIH-NIAID R21 A1072615-01 (HP).

\section{REFERENCES}

Abromaitis, S. and Stephens, R.S. (2009). Attachment and entry of Chlamydia have distinct requirements for host protein disulfide isomerase. PLoS Pathogens Apr;5(4), e1000357. Epub 2009 Apr 3.

Altschul, S. F., Gish, W., Miller, W., Myers, E. W. and Lipman, D. J. (1990). Basic local alignment search tool. Fournal of Molecular Biology 215, 403-410.

Ashburner, M., Ball, C. A., Blake, J. A., Botstein, D., Butler, H., Cherry, J. M., Davis, A.P., Dolinski, K., Dwight, S.S., Eppig, J. T., Harris, M. A., Hill, D. P., Issel-Tarver, L., Kasarskis, A., Lewis, S., Matese, J. C., Richardson, J. E., Ringwald, M., Rubin, G. M. and Sherlock, G. (2000). Gene ontology, tool for the unification of biology. The Gene Ontology Consortium. Nature Genetics 25, 25-29.

Bairoch, A. (1999). The ENZYME data bank in 1999. Nucleic Acids Research 27, 310-311.

Bernsel, A., Viklund, H., Falk, J., Lindahl, E., von Heijne, G. and Elofsson, A. (2008). Prediction of membrane-protein topology from first principles. Proceedings of the National Academy of Sciences, USA 105, $7177-7181$

Bernsel, A., Viklund, H., Hennerdal, A. and Elofsson, A. (2009). TOPCONS, consensus prediction of membrane protein topology. Nucleic Acids Research 37(Web Server issue), W465-8. doi:10.1093/nar/gkp363

Bi, S., Hong, P. W., Lee, B. and Baum, L. G. (2011). Galectin-9 binding to cell surface protein disulfide isomerase regulates the redox environment to enhance T-cell migration and HIV entry. Proceedings of the National Academy of Sciences, USA 108, 10650-10655.

Blair, P. L. and Carucci, D. J. (2005). Functional proteome and expression analysis of sporozoites and hepatic stages of malaria development. Current Topics in Microbiology and Immunology 295, 417-438.

Bozdech, Z., Zhu, J., Joachimiak, M. P., Cohen, F. E., Pulliam, B. and DeRisi, J. L. (2003). Expression profiling of the schizont and trophozoite stages of Plasmodium falciparum with a long-oligonucleotide microarray. Genome Biology 4, R9. Epub 2003 Jan 31.

Briesemeister, S., Blum, T., Brady, S., Lam, Y., Kohlbacher, O. and Shatkay, H. (2009). SherLoc2, a high-accuracy hybrid method for predicting subcellular localization of proteins. Fournal of Proteome Research 8, 5363-5366.

Carlton, J. M., Angiuoli, S. V., Suh, B. B., Kooij, T., Pertea, M., Silva, J. C., Ermolaeva, M. D., Allen, J. E., Selengut, J. D., Koo, H. L., Peterson, J. D., Pop, M., Kosack, D. S., Shumway, M. F., Bidwell, S. L., Shallom, S. J., Van Aken, S.E., Riedmuller, S. B., Feldylum, T.V., Cho, J. K., Quackenbush, J., Sedegah, M., Shoalbi, A., Cummings, L. M., Florens, L., Yates, J. R., Raine, D. J., Sinden, R. E., Haris, M. A., Cunningham, D. A., Preiser, P. R., Bergman, L.W., Vaidya, A., Van Lin, L.H., Janse, C. J., Waters, A.P., Smith, H. O., White, O.R., Salzberg, J., Venter, C.,
Fraser, C. M., Hoffman, S. L., Gardner, M. J. and Carucci, J. (2002). Genome sequence and comparative analysis of the model rodent malaria parasite Plasmodium yoelii yoelii. Nature 419, 512-519.

Carucci, D. J., Yates, J.R., III and Florens, L. (2002). Exploring the proteome of Plasmodium. International fournal for Parasitology 32, 1539-1542.

Chou, K.-C., and Shen, H.-B. (2007). Euk-mPLoc, a fusion classifier for large-scale eukaryotic protein subcellular location prediction by incorporating multiple sites. Fournal of Proteome Research 6, 1728-1734. Cociancich, S. O., Park, S. S., Fidock, D. A. and Shahabuddin, M. (1999). Vesicular ATPase-overexpressing cells determine the distribution of malaria parasite oocysts on the midguts of mosquitoes. Fournal of Biological Chemistry 274, 12650-12655.

Creasey, A. M., Ranford Cartwright, L. C., Moore, D. J., Williamson, D.H., Wilson, R. J.M., Walliker, D. and Carter, R. (1993). Uniparental inheritance of the mitochondrial gene cytochrome-b in Plasmodium falciparum. Current Genetics 23, 360-364.

Deligianni, E., Morgan, R. N., Bertuccini, L., Kooij, T.W., Laforge, A., Nahar, C., Poulakakis, N., Schüler, H., Louis, C., Matuschewski, A. and Siden-Kiamos, I. (2011). Critical role for a stage-specific actin in male exflagellation of the malaria parasite. Cellular Microbiology 13, 1714-1730.

Doolan, D. L., Southwood, S., Freilich, D. A., Sidney, J., Graber, N. L., Shatney, L., Bebris, L., Florens, L., Dobano, C., Witney, A. A., Appella, E., Hoffman, S. L., Yates, J. R., Carucci, D. J. and Sette, A. (2003). Identification of Plasmodium falciparum antigens by antigenic analysis of genomic and proteomic data. Proceedings of the National Academy of Sciences, USA 100, 9952-9957.

Emanuelsson, O., Brunak, S., von Heijne, G. and Nielsen, H. (2007). Locating proteins in the cell using TargetP, SignalP and related tools. Nature Protocols 2, 953-971.

Florens, L., Washburn, M.P., Raine, J.D., Anthony, R. M., Grainger, M., Haynes, J.D., Moch, J. K., Muster, N., Sacci, J. B., Tabb, D. L., Witney, A.A., Wolters, D., Wu, Y., Gardner, M. J., Holder, A. A., Sinden, R. E., Yates, J. R. and Carucci, D. J. (2002). A proteomic view of the Plasmodium falciparum life cycle. Nature 419, $520-526$.

Forslund, K., and Sonnhammer, E. L. L. (2008). Predicting protein function from domain content. Bioinformatics 24, 1681-1687.

Foth, B. J., Zhang, N., Chaal, B.K., Sze, S. K., Preiser, P.R. and Bozdech, Z. (2011). Quantitative time-course profiling of parasite and host cell proteins in the human malaria parasite Plasmodium falciparum. Molecular and Cellular Proteomics 10, M110.006411. Epub 2011 May 10.

Garg, A. and Raghava, G. (2008). ESLpred2, improved method for predicting subcellular localization of eukaryotic proteins. BMC Bioinformatics 9, 503.

Gass, R.F. (1977). Influences of blood digestion on the development of Plasmodium gallinaceum (Brumpt). in the midgut of Aedes aegypti (L.). Acta Tropica 34, 127-140

Gass, R.F. and Yeates, R.A. (1979). In vitro damaged of cultured ookinetes of Plasmodium gallinaceum by digestive proteinases from susceptible Aedes aegypti. Acta Tropica 36, 243-252.

Gomes-Santos, C.S., Braks, J., Prudencio, M., Carret, C., Gomes, A. R., Pain, A., Feltwell, T., Khan, S., Waters, A., Janse, C., Mair, G. R. and Mota, M. M. (2011). Transition of Plasmodium sporozoites into liver stage-like forms is regulated by the RNA binding protein Pumilio. PLoS Pathogens 7, e1002046. Epub 2011 May 19.

Hadley, T. J. and Miller, L. H. (1988). Invasion of erythrocytes by malaria parasites, Erythrocyte ligands and parasite receptors. Progress in Allergy 41, 49-71.

Hall, N., Karras, M., Raine, J.D., Carlton, J. M., Kooij, T. W. J., Berriman, M., Florens, L., Janssen, C.S., Pain, A., Christophides, G. K., James, K., Rutherford, K., Harris, B., Harris, D. B., Churcher, C., Quail, M. A., Ormond, D., Doggett, J., Trueman, H.E., Mendoza, J., Bidwell, S.L., Rajandream, M.-A., Carucci, D. J., Yates, I. J. R., Kafatos, F. C., Janse, C. J., Barrell, B., Turner, C. M. R., Waters, A. P. and Sinden, R. E. (2005). A comprehensive survey of the Plasmodium life cycle by genomic, transcriptomic, and proteomic analyses. Science $\mathbf{3 0 7}, 82-86$.

Han, Y.S. and Barillas-Mury, C. (2002). Implications of time bomb model of ookinete invasion of midgut cells. Insect Biochemistry and Molecular Biology 32, 1311-1316.

Hawkins, T., Luban, S. and Kihara, D. (2006). Enhanced automated function prediction using distantly related sequences and contextual association by PFP. Protein Science 15, 1550-1556.

Hernandez-Romano, J., Rodriguez, M.H., Pando, V., TorresMonzom, J.A., Alvarado-Delgado, A., Lecona Valera, A. N., Ramos, R. A., Martinez-Barnetche, J. and Rodriguez, M. C. (2011). 
Conserved peptide sequences bind to actin and enolase on the surface of Plasmodium berghei ookinetes. Parasitology 138, 1341-1353.

Horton, P., Park, K.-J., Obayashi, T., Fujita, N., Harada, H., AdamsCollier, C. J. and Nakai, K. (2007). WoLF PSORT, protein localization predictor. Nucleic Acids Research 35, (Web Server issue), W585-587.

Hunter, S., Apweiler, R., Attwood, T. K., Bairoch, A., Bateman, A. Binns, D., Bork, P., Das, U., Daugherty, L., Duquenne, L., Finn, R. D., Gough, J., Haft, D., Hulo, N., Kahn, D., Kelly, E., Laugraud, A., Letunic, I., Lonsdale, D., Lopez, R., Madera, M., Maslen, J., McAnulla, C., McDowall, J., Mistry, J., Mitchell, A., Mulder, N., Natale, D., Orengo, C., Quinn, A. F., Selengut, J. D., Sigrist, C. J., Thimma, M., Thomas, P. D., Valentin, F., Wilson, D., Wu, C. H. and Yeats, C. (2009). InterPro, the integrative protein signature database. Nucleic Acids Research 37, D211-D215

Kappe, S. H.I., Gardner, M. J., Brown, S. M., Ross, J., Matuschewski, K., Ribeiro, J. M., Adams, J.H., Quackenbush, J., Cho, J., Carucci, D. J., Hoffman, S. L. and Nussenzweig, V. (2001). Exploring the transcriptome of the malaria sporozoite stage. Proceedings of the National Academy of Sciences, USA 98, 9895-9900.

Kelley, L. A. and Sternberg, M. J. (2009). Protein structure prediction on the Web, a case study using the Phyre server. Nature Protocols 4, 363-371. Khan, S. M., Franke-Fayard, B., Mair, G. R., Lasonder, E., Janse, C. J., Mann, M. and Waters, A. P. (2005). Proteome analysis of separated male and female gametocytes reveals novel sex-specific Plasmodium biology. Cell $121,675-687$

Kooij, T. W. A., Janse, C. J. and Waters, A.P. (2006). Plasmodium postgenomics, better the bug you know? Nature Reviews Microbiology $\mathbf{4}$ 344-357.

Krogh, A., Larsson, B., von Heijne, G. and Sonnhammer, E. L. (2001) Predicting transmembrane protein topology with a hidden Markov model, application to complete genomes. Fournal of Molecular Biology 305, $567-580.5$.

Krotoski, W. A. (1985). Discovery of the hypnozoite and a new theory of malarial relapse. Transactions of the Royal Society of tropical Medicine and Hygiene 79, 1-11.

Lal, K., Prieto, J.H., Bromley, E., Sanderson, S. J., Yates, J. R., Wastling, J. M., Tomley, F.M. and Sinden, R.E. (2009) Characterisation of Plasmodium invasive organelles; an ookinete microneme proteome. Proteomics 9, 1142-1151.

Lasonder, E., Ishihama, Y., Andersen, J. S., Vermunt, A. M., Pain, A., Sauerwein, R.W., Eling, W. M., Hall, N., Waters, A.P., Stunnenberg, H. G. and Mann, M. (2002). Analysis of the Plasmodium falciparum proteome by high-accuracy mass spectrometry. Nature 419 , 537-542.

Lasonder, E., Janse, C. J., van Gemert, G.-J., Mair, G.R., Vermunt, A. M., Douradinha, B. G., van Noort, V., Huynen, M. A., Luty, A. J., Kroeze, H., Khan, S. M., Sauerwein, R. W., Waters, A. P., Mann, M. and Stunnenberg, H. G. (2008). Proteomic profiling of Plasmodium sporozoite maturation identifies new proteins essential for parasite development and infectivity. PLoS Pathogens 4, e1000195. Epub 2008 Oct 31 .

Lobley, A. E., Nugent, T., Orengo, C. A. and Jones, D. T. (2008). FFPred, an integrated feature-based function prediction server for vertebrate proteomes. Nucleic acids research 36, (Web Server issue), W297-302.

Mair, G., Braks, J. A. M., Garver, L. S., Wiegant, J. C. A. G., Hall, N., Dirks, R. W., Khan, S. M., Dimopoulos, G., Janse, C. J. and Waters, A. P. (2006). Regulation of sexual development of Plasmodium by translational repression. Science 313, 667-669.

Martin, R., Ginsburg, H. and Kirk, K. (2009). Membrane transport proteins of the malaria parasite. Molecular Microbiology 74, 518-528. Meek, B., Back, J. W., Klaren, V. N., Speijer, D. and Peek, R. (2002), Conserved regions of protein disulfide isomerase are targeted by natural IgA antibodies in humans. International Immunology 11, 1291-1301.

Mulder, N. J., Apweiler, R., Attwood, T. K., Bairoch, A., Bateman, A., Binns, D., Bork, P., Buillard, V., Cerutti, L., Copley, R., Courcelle, E., Das, U., Daugherty, L., Dibley, M., Finn, R., Fleischmann, W. Gough, J., Haft, D., Hulo, N., Hunter, S., Kahn, D., Kanapin, A., Kejariwal, A., Labarga, A., Langendijk-Genevaux, P.S., Lonsdale, D., Lopez, R., Letunic, I., Madera, M., Maslen, J., McAnulla, C., McDowall, J., , Mistry, J., Mitchell, A., Nikolskaya, A. N., Orchard, S., Orengo, C., Petryszak, R., Selengut, J. D., Sigrist, C. J., Thomas, P. D., Valentin, F., Wilson, D. Wu, C. H. and Yeats, C. (2007). New developments in the InterPro database. Nucleic Acids Research 35, (Database issue). D224-D228.

Muller, H.-M., Crampton, J. M., Della Torre, A., Sinden, R. E. and Frisanti, A. (1993). Members of a trypsin gene family in Anopheles gambiae are induced in the gut by bloodmeal. EMBO Fournal 12, 2891-2900.
Naguleswaran, A., Alaeddine, F., Guionaud, C., Vonlaufen, N., Sonda, S., Jenoe, P., Mevissen, M. and Hemphill, A. (2005). Neospora caninum protein disulfide isomerase is involved in tachyzoite-host cell interaction. International Fournal for Parasitology 35, 1459-1472.

Nijhout, M. M. and Carter, R. (1978). Gamete development in malarial parasites, bicarbonate-dependent stimulation by $\mathrm{pH}$ in vitro. Parasitology 76, 39-53

Nirmalan, N., Sims, P.F. G. and Hyde, J. E. (2004). Quantitative proteomics of the human malaria parasite Plasmodium falciparum and its application to studies of development and inhibition. Molecular Microbiology 52, 1187-1199.

Okamoto, N., Spurck, T.P., Goodman, C.D. and McFadden, G. I. (2008). The apicoplast and mitochondrion in gametocytogenesis of Plasmodium falciparum. Eukaryotic Cell 8, 128-132.

Olszewski, K. L., Mather, M. W., Morrisey, J. M., Garcia, B. A., Vaidya, A. B., Rabinowitz, J. D. and Llinas, M. (2010). Branched tricarboxylic acid metabolism in Plasmodium falciparum. Nature 466, 774-778.

Paton, M. G., Barker, G. C., Matsuoka, H., Ramesar, J., Janse, C. J., Waters, A.P. and Sinden, R. E. (1993). Structure and expression of a conserved and post-transcriptionally regulated gene encoding a surface protein of the sexual stages from malaria parasite Plasmodium berghei. Molecular and Biochemical Parasitology 59, 263-275.

Peng, J., Elias, J. E., Thoreen, C. C., Licklider, L. J. and Gygi, S. P. (2003). Evaluation of multidimensional chromatography coupled with tandem mass spectrometry (LC/LC-MS/MS). for large-scale protein analysis, the yeast proteome. Fournal of Proteome Research 2, 43-50.

Sam-Yellowe, T. Y., Del Rio, R. A., Fujioka, H., Aikawa, M., Yang, J.C. and Yakubu, Z. (1998). Isolation of merozoite rhoptries, identification of novel rhoptry-associated proteins from Plasmodium yoelii, $P$. berghei and conserved interspecies reactivity of organelles and proteins with P. falciparum rhoptry-specific antibodies. Experimental Parasitology 89, 271-284

Sam-Yellowe, T. Y., Florens, L., Wang, T., Raine, J. D., Carucci, D. Sinden, R. E. and Yates, J. R. (2004). Proteome Analysis of RhoptryEnriched Fractions Isolated from Plasmodium Merozoites. Fournal of Proteome Research 3, 995-1001.

Scholz, S. M., Simon, N., Lavazec, C., Dude, M.-A., Templeton, T. J. and Pradel, G. (2007). PfCCp proteins of Plasmodium falciparum, Gametocyte-specific expression and role in complement-mediated inhibition of exflagellation. International fournal for Parasitology 38, 327-340. Shahabuddin, M. and Pimenta, P. F. P. (1998). Plasmodium gallinaceum preferentially invades vesicular ATPase-expressing cells in Aedes aegypti midgut. Proceedings of the National Academy of Sciences U.S.A. 95, 33853389

Silvestrini, F., Bozdech, Z., Lanfrancotti, A., Di Guilio, E., Bultrini, E., Picci, L., deRisi, J. L., Pizzi, E. and Alano, P. (2005). Genome-wide identification of genes upregulated at the onset of gametocytogenesis in Plasmodium falciparum. Molecular and Biochemical Parasitology 143, 100-110.

Sims, P.F. and Hyde, J. E. (2006). Proteomics of the human malaria parasite Plasmodium falciparum. Expert Reviews in Proteomics 3, 87-95. Sinden, R. E. (1978). Cell Biology. In Rodent Malaria. (ed. KillickKendrick, R and Peters, W. A.), pp. 85-186. Academic Press, New York. Sinden, R. E. (1983). The cell biology of sexual development in plasmodium. Parasitology 86, 7-28

Sinden, R. E., Canning, E. U. and Spain, B. (1976). Gametogenesis and fertilization in Plasmodium yoelii nigeriensis, a transmission electron microscope study. Proceedings of the Royal Society London B 193, 55-76.

Sinden, R.E., Canning, E. U., Bray, R. S. and Smalley, M. E. (1978) Gametocyte and gamete development in Plasmodium falciparum Proceedings of the Royal Society London B 201, 375-399.

Sinden, R.E., Talman, A., Marques, S. R., Wass, M.N. and Sternberg, M. J. E. (2010). The flagellum in malarial parasites. Current Opinion in Microbiology 13, 491-500.

Singh, S., Plassmeyer, M., Gaur, D. and Miller, L. H. (2007). Mononeme, a new secretory organelle in Plasmodium falciparum merozoites identified by localization of rhomboid-1 protease. Proceedings of the National Academy of Sciences U.S.A. 104, 20043-20048.

Slavic, K., Delves, M. J., Prudencio, M., Talman, A. M., Straschil, U., Derbyshire, E.T., Xu, Z., Sinden, R.E., Mota, M. M., Morin, C. Tewari, R., Krishna, S. and Staines, H. M. (2011). Use of a selective inhibitor to define the chemotherapeutic potential of the plasmodial hexose transporter in different stages of the parasite's life cycle. Antimicrobial Agents and Chemotherapy 55, 2824-2830.

Southworth, P., Hyde, J. and Sims, P. (2011). A mass spectrometric strategy for absolute quantification of Plasmodium falciparum proteins of low abundance. Malaria fournal 10, 315. 
Stanway, R. R. (2007). The ookinete surface proteome of Plasmodium berghei. PhD thesis. Imperial College London. 223p.

Straschil, U., Talman, A. M., Ferguson, D. J. P., Bunting, K. A., Xu, Z., Bailes, E., Sinden, R. E., Holder, A. A., Smith, E. F., Coates, J. C. and Tewari, R. (2010). The armadillo repeat protein PF16 is essential for flagellar structure and function in Plasmodium male gametes. PLoS One 5, e12901.

Talman, A. M. (2010). Molecular studies on Plasmodium sexual development. PhD thesis. Imperial College London, 176p.

Talman, A. M., Lacroix, C., Marques, S.R., Blagborough, A. M., Carzaniga, R., Ménard, R. and Sinden, R. E. (2011). PbGEST mediates malaria transmission to both mosquito and vertebrate host. Molecular Microbiology 82, 462-474.

Tarun, A.S., Peng, X., Dumpit, R.F., Ogata, Y., Silva-Rivera, H., Camargo, N., Bergman, L. W. and Kappe, S. H. I. (2008). A combined transcriptome and proteome survey of malaria parasite liver stages. Proceedings of the National Academy of Sciences, USA 105, 305-310. Thompson, J. and Sinden, R. E. (1994). In situ detection of Pbs 21 mRNA during sexual development of Plasmodium berghei. Molecular and Biochemical Parasitology 68, 189-196.

Treeck, M., Sanders, J. L., Elias, J. E. and Boothroyd, J. C. (2011). The phosphoproteomes of Plasmodium falciparum and Toxoplasma gondii reveal unusual adaptations within and beyond the parasites' boundaries. Cell Host and Microbe 10, 410-419.

Tufet-Bayona, M., Janse, C. J., Khan, S. M., Waters, A.P., Sinden, R. E. and Franke-Fayard, B. (2009). Localisation and timing of expression of putative Plasmodium berghei rhoptry proteins in merozoites and sporozoites. Molecular and Biochemical Parasitology 166, 22-31.

van Schaijk, B. C. L., van Dijk, M. R., van de Vegte-Bolmer, M., van Gemert, G.-J., van Dooren, M.W., Eksi, S., Roeffen, W. F. G.,
Janse, C. J., Waters, A.P. and Sauerwein, R. W. (2006). Pfs47, paralog of the male fertility factor Pfs $48 / 45$, is a female specific surface protein in Plasmodium falciparum. Molecular and Biochemical Parasitology 149 216-222.

Vontas, J., Siden-Kiamos, I., Papagiannakis, G., Karras, M., Waters, A.P. and Louis, C. (2005). Gene expression in Plasmodium berghei ookinetes and early oocysts in a co-culture system with mosquito cells. Molecular and Biochemical Parasitology 139, $1-13$.

Wang, Q., Brown, S., Roos, D. S., Nussenzweig, V. and Bhanot, P. (2004). Transcriptome of axenic liver stages of Plasmodium yoelii. Molecular and Biochemical Parasitology 137, 161-168.

Wass, M. N., and Sternberg, M. J.E. (2008). ConFunc-functional annotation in the twilight zone. Bioinformatics 24, 798-806.

Wass, M. N., Kelley, L.A. and Sternberg, M. J.E. (2010) 3DLigandSite, predicting ligand-binding sites using similar structures. Nucleic Acids Research 38, (Web Server issue), W469-W473.

Watson, K., Edwards, R. J., Shaunak, S., Parmelee, D. C., Sarraf, C., Gooderham, N. J. and Davies, D. S. (1995). Extra-nuclear location of histones in activated human peripheral blood lymphocytes and cultured T-cells. Biochemical Pharmacology 50, 299-309.

Wells, T.N.C., Alonso, P.L. and Gutteridge, W.E. (2009). New medicines to improve control and contribute to the eradication of malaria. Nature Reviews Drug Discovery 8, 879-891.

Yeh, E. and DeRisi, J. L. (2011). Chemical rescue of malaria parasites lacking an apicoplast defines organelle function in blood-stage Plasmodium falciparum. PLoS Biology 9, e1001138.

Yu, C.-S., Chen, Y.-C., Lu, C.-H. and Hwang, J.-K. (2006). Prediction of protein subcellular localization. Proteins, Structure, Function, and Bioinformatics 64, 643-651. 